Journal Homepage: https://journalofforensicexpert.id

e-ISSN: 2808-5248

PUSLABFOR BARESKRIM POLRI

\title{
ANALISIS FORENSIK KEGAGALAN KONSTRUKSI STRUKTUR BANGUNAN 3 LANTAI DENGAN SAP (STRUCTURE ANALYSIS PROGRAM) 2000
}

\author{
Tatang Kukuh Wibawa*, Ilham Syaekhul Amri \\ Puslabfor Bareskrim Polri, Indonesia \\ ${ }^{*}$ Correspondence E-mail: tatangkukuhw@yahoo.com
}

\section{ARTICLE INFO}

Article history:

Received 1 July 2021

Revised 20 September 2021

Accepted 5 October 2021

Available online 19 October 2021

Keywords: construction failure,

forensic analysis, sap 2000, column

Kata kunci: kegagalan konstruksi, analisis forensik, sap 2000, kolom

DOI:

https://doi.org/10.54579/jfe.v1i3.8

\section{How to Cite :}

Wibawa, T. K., Amri, I. S. (2021).

Analisis Forensik Kegagalan

Konstruksi Struktur Bangunan 3

Lantai Dengan Sap (Structure

Analysis Program) 2000. Journal of

Forensic Expert, 1(3), 19-30.

\begin{abstract}
A Building 3-storey construction project using reinforced concrete construction was failure and collapse in Johor Baru Central Jakarta. The impact of construction failure is work accidents (injury and death), damage to construction/infrastructure, and there are legal consequences for failures that occur and the causes of failure. The research method is to examine the condition of the installed structure, check the level of damage, test the quality of concrete, structural modeling with SAP (Structure Analysis Program) 2000, analyze and calculate the strength of the column cross section, analyze and conclude from the overall inspection results with implementing regulations and reinforcement in SNI 03 -2847-2002. The results of the study concluded that the initial failure was in the column with a size of $33 \times 10$ centimeters on the south side of the 1 st floor with a buckling type failure that caused it to collapse due to pressure from above (floors 2 and 3). The results of the structural modeling of the SAP 2000 program and the calculation of the column cross-sectional strength obtained that the cross-sectional strength capacity of the column is 32.80 tons, this value is still able/safe to withstand the load of the structure above it. The failure and collapse of the column was caused by the implementation of the principles and details of the reinforcement that were not standardized and did not follow the rules of SNI 2847:2013 on the spacing of the stirrups and the details of bending of the iron.
\end{abstract}

\section{ABSTRAK}

Sebuah proyek konstruksi bangunan 3 lantai menggunakan konstruksi struktur beton bertulang mengalami kegagalan konstruksi dan keruntuhan di Johor Baru Jakarta Pusat. Dampak yang ditimbulkan dari kegagalan konstruksi yaitu kecelakaan kerja (luka dan meninggal), rusaknya konstruksi/infrastruktur, dan terdapat konsekuensi hukum atas kegagalan yang terjadi dan penyebab kegagalan. Metode penelitian melakukan pemeriksaan kondisi struktur terpasang, pemeriksaan tingkat kerusakan, pengujian mutu beton, pemodelan struktur dengan SAP (Structure Analysis Program) 2000, melakukan analisis dan perhitungan kekuatan penampang kolom, mengalisa dan menyimpulkan dari keseluruhan hasil pemeriksaan dengan peraturan pelaksanaan dan penulangan pada SNI 03-2847-2002. Hasil penelitian disimpulkan bahwa keruntuhan awal berada pada Kolom ukuran $33 \times 10$ centimeter di bagian sisi Selatan lantai 1 dengan keruntuhan tipe buckling/tekuk sehingga menyebabkan hancur akibat tekanan dari arah atas (lantai 2 dan 3). Hasil pemodelan struktur Program SAP 2000 dan perhitungan kekuatan penampang kolom didapatkan kapasitas kekuatan penampang kolom yaitu 32,80 ton, nilai terebut masih mampu/aman menahan beban struktur diatasnya. Kegagalan dan keruntuhan kolom diakibatkan pelaksanaan prinsip dan detail penulangan yang tidak standart dan tidak mengikuti kaidah SNI 2847:2013 pada panjang spasi Sengkang dan detail tekukan besi. 
Wibawa, T. K., Amri, I. S. Analisis Forensik Kegagalan Konstruksi ...

\section{Pendahuluan}

Kegagalan konstruksi bangunan merupakan fenomena yang terjadi seiring dengan laju pembangunan diberbagai sektor industri untuk percepatan dan meningkatkan pertumbuhan ekonomi di suatu negara. Hal tersebut terjadi pada sektor konstruksi yang berdampak langsung pada peningkatkan volume proyek konstruksi. Kesadaran akan pentingnya peningkatan pemahaman dan kewaspadaan terhadap potensi kegagalan konstruksi dan kegagalan bangunan merupakan salah satu upaya preventif terhadap kelangsungan dan keberlanjutan konstruksi. (Muhammad Amry,2019)

Dunia kerja, khususnya pada bidang kontruksi memiliki angka kecelakaan kerja sangat besar, Dibuktikan dengan data Badan Penyelenggara Jaminan Kesehatan (BPJS) Ketenaga kerjaan, hingga akhir 2015 sudah terjadi kecelakaan kerja sebanyak 105.182 kali. Sementara itu, untuk itu kecelakaan berat yang mengakibatkan kematian sekitar 2.375 kematian dari semua jumlah kecelakaan kerja. Dirjen Pembimbing Pengawasan Ketenaga kerjaan serta Keselamatan dan Kesehatan Kerja (PPK dan K3) Kementrian Ketenagakerjaan (Kemnaker) mengungkapkan, kecelakaan kerja dari tahun ke tahun sudah ada kemajuan jumlah kecelakaan yang meningkat. Sehingga dari semua jumlah kecelakaan kerja tiap tahun selalu ada peningkatan sampai 5\%. Namun untuk kecelakaan kerja yang berat peningkatannya sangat lumayan besar yakin kira-kira $5 \%-10 \%$ setiap tahun. Faktor-faktor yang beresiko menyebabkan kecelakaan konstruksi adalah Faktor manusia, Faktor lingkungan kerja, Faktor peralatan. Hubungan antar faktor penyebab kecelakaan yang teridentifikasi mempunyai hubungan yang searah dan sebab akibat atau timbal balik. (Prayitno Osmar Dangga, 2020)

Kegagalan bangunan dan kegagalan konstruksi dapat disebabkan oleh faktor teknis maupun faktor non teknis. Faktor teknis karena adanya penyimpangan proses pelaksanaan yang tidak memenuhi spesifikasi teknis yang disepakati dalam kontrak, sedangkan faktor non teknis lebih disebabkan karena proses pra kontrak (Bidding) maupun tidak kompetenya Badan Usaha, tenaga kerja, tidak profesionalnya tata kelola manajerial antara pihak-pihak yang terlibat dalam proyek konstruksi serta lemahnya pengawasan/supervise. Dalam konteks proyek gedung, kegagalan konstruksi dan kegagalan bangunan banyak terjadi pada elemen struktur bangunan dengan rata-rata penyimpangan sebesar 4,36\% dari nilai kontrak, disusul oleh atap (2,53\%), pondasi $(0,15 \%)$, utilitas $(0,12 \%)$ dan finishing $(0,07 \%)$. (Yustinus Eka Wiyana, 2012)

Kegagalan dalam struktur bangunan terjadi karena berbagai penyebab umum nya pada saat proses konstruksi dan pelaksanalah yang bertanggung jawab untuk kegagalan. Proses perencanaan saat membangun struktur, pengujian tanah, pasir, beton dan lainnya harus dilakukan. Laporan forensik struktur yang disusun dapat menemukan kesalahan dalam desain, atas dasar dari hasil pengujian sampel akan mengidentifikasi penyebab kegagalan \& kekuatan struktur. (Rekha Shinde and Kundan Meshram, 2020)

Sebuah pekerjaan kontruksi bangunan 3 (tiga) lantai yang difungsikan sebagai rumah mengalami kegagalan konstruksi dan keruntuhan pada jumat tanggal 26 April 2019 di Johor Baru Jakarta Pusat, dari kejadian tersebut mengakibatkan meninggalnya 3 (tiga) orang, 1 korban kritis dan 11 lainnya luka-luka, menimpa mikrolet dan ojek online. Bangunan yang mengalami keruntuhan tersebut masih dalam tahap konstruksi dan belum diserah terimakan ke pemilik. (Tatang Guritno. 2019) 


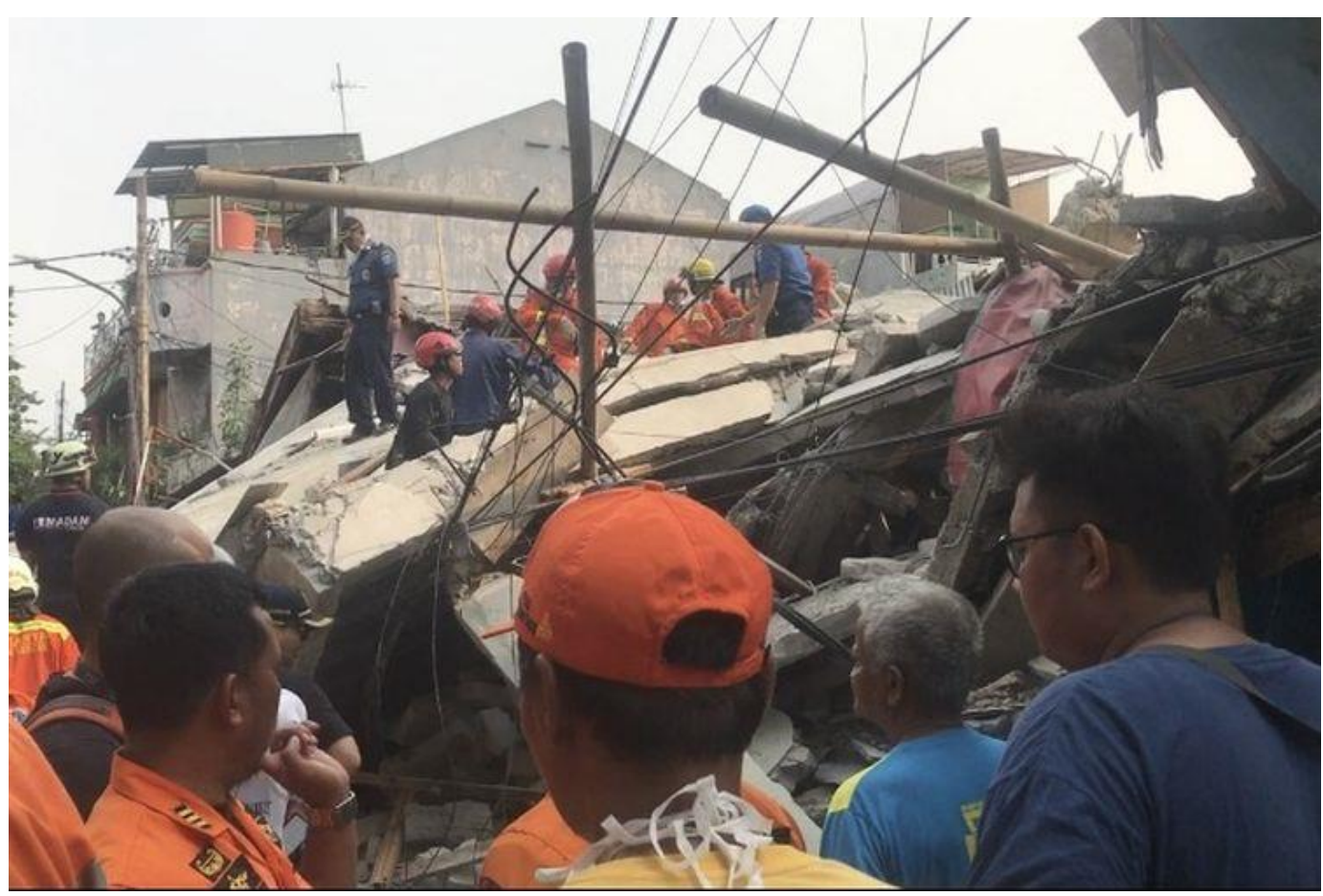

Gambar 1. Bangunan 3 Lantai yang mengalami kegagalan pada saat evakuasi.

https:/megapolitan.kompas.com/read/2019/04/27/09131121/fakta-rumah-ambruk-di-johar-baru-bangunan-ilegal-yang-makankorban-jiwa?page=all.

Dalam kaitannya dengan pemeriksaan kegagalan, setelah bangunan mengalami keruntuhan maka proses selanjutnya adalah periksa dukumen as-built, posisinya, kondisinya, dan keadaan lain yang menjadi bukti. Bukti ini akan berperan penting dalam menentukan penyebab kegagalan yang paling mungkin dan faktor-faktor yang berkontribusi. Beberapa bukti ini tahan lama dan akan tetap utuh selama jangka waktu tertentu. Namun, bukti tertentu bersifat mudah rusak dan oleh karena itu harus segera didokumentasikan. Maksanakan proses pemeriksaan dengan mengkonfigurasi kegagalan dapat memberikan informasi berharga tentang kemungkinan mekanisme keruntuhan dan asal kegagalan, dan juga dapat berfungsi untuk menghilangkan beberapa mekanisme dari pertimbangan lebih lanjut. Oleh karena itu penting bahwa konfigurasi keruntuhan diperiksa dan di foto secepat mungkin. (Robert T. Ratay, Ph.D., P.E. 2000).

Analisis kerusakan bangunan pada hakekatnya dilakukan berdasar pada pengetahuan tentang konstruksi bangunan secara umum. Penilaian mengenai kerusakan bangunan dibagi menjadi dua kelompok yaitu: 1) Analisis berdasarkan stabilitas, dan 2) Analisis berdasarkan Hogrotermal. Analisis berdasarkan stabilitas dapat dibagi dalam beberapa kelompok yaitu: 1) Struktur dan stabilitas. 2) Distorsi dan criteria. 3) Pengaruh bentuk struktur terhadap gejala kerusakan. 4) Ketidakstabilan: tinjauan dari beban luar. 5) Ketidakstabilan: bentuk struktur dan definisi. 6) Ketidakstabilan di dalam struktur: tinjauan dari struktur bawah. 7) Ketidakstabilan dalam proses produksi. 8) Ketidakstabilan material. 9) Ukuran ketidakstabilan: pergerakan air. 10) Ukuran ketidakstabilan: pergerakan suhu. (Cook dan Hinks, 1992)

Analisa Forensik dalam pemeriksaan kegagalan struktur merupakan proses ilmiah (didasari oleh ilmu pengetahuan) dalam melakukan kegiatan pemeriksaan, mengumpulkan bukti-bukti yang ada di tempat kejadian perkara (TKP), menganalisis dan kemudian menyimpulkan penyebab kegagalan. Pemeriksaan di tempat kejadian perkara dimulai dengan pemeriksaan 
Wibawa, T. K., Amri, I. S. Analisis Forensik Kegagalan Konstruksi ...

tingkat kerusakan akibat kegagalan struktur yang paling utama, kemudian melakukan pengumpulan dan pemeriksaan suatu barang bukti dengan instrument/alat pemeriksaan konstruksi, memodelkan struktur dan menghitung kapasitas ultimate struktur dibandingkan kapasitas nominal struktur, serta pemeriksaan metode dan pelaksanaan konstrukti dalam kaidah standart acuan (code).

Pada struktur stabil apabila dikenakan beban, struktur tersebut akan mengalami perubahan (deformasi) yang lebih kecil dibanding dengan struktur yang tidak stabil. Hal ini disebabkan karena struktur stabil memiliki kekuatan dan kestabilan dalam menahan beban. (Daniel L. Schodek. 1999)

Pemodelan struktur dengan program SAP 2000 merupakan progam computer yang dirangcang untuk perancangan atau memodelkan suatu struktur meliputi struktur beton, struktur baja maupun struktur kayu dengan penampang tertentu kemudian menganalisis untuk mendapatkan kriteria desain dan analisa desain dari sebuat struktur. Hasil perhitungan dengan program SAP 2000 yaitu analisa static dan dinamik dari beban yang bekerja, penampang struktur dan perilaku stuktur. Proses Desain dan analisa program SAP 2000 meliputi pemilihan model struktur, penampang struktur, kondisi pembebanan (load condition), analisis model struktur, nilai deformasi struktur, gaya dalam yang bekerja (gaya aksial, momen, puntir), tegangan elemen struktur.

Tindakan-tindakan untuk mengurangi kegagalan konstruksi yaitu : Perlu di adakan pelatihan dan sertifikasi tenaga konstruksi gedung untuk menambah kemampuan dan keterampilan tenaga kerja di bidang konstruksi banguan gedung Perlu peningkatan kompetensi kerja dalam dunia konstruksi untuk meningkatkan kualitas Sumber Daya Manusia (SDM) di bidang konstruksi yang dimiliki perusahaan, yang juga akan meningkatkan kualitas perusahaan jasa konstruksi, Untuk mencapai sasaran mutu proyek maka perencanaan desain harus mendetail untuk memudahkan dalam pelaksanaan konstruksi. Penyempurnaan Undang-undang dan Peraturan tentang Kegagalan Konstruksi perlu dilakukan segera. Review desain perlu dilakukan oleh penyedia jasa/ kontraktor untuk memudahkan kontraktor dalam pelaksanaan konstruksi dan Pengawasan Rutin harus dilakukan Engineer/Konsultan pengawas agar mutu dan kualitas bangunan konstruksi sesuai dengan yang diharapkan. (Rina Rusdiani, 2017).

\section{Metode}

Metode penelitian ini adalah pertama melakukan pemeriksaan kondisi struktur terpasang yang mengalami kegagalan dengan memeriksa dimensi, ukuran meliputi dimensi kolom, balok, plat lantai dan data struktur lainnnya kemudian membuat gambar konstruksi. Kedua melaksanakan pemeriksaan tingkat kerusakan di lokasi tempat kejadian perkara (TKP) untuk menentukan lokasi pertama atau awal struktur mengalami kegagalan dengan teknik cheklist gambar konstruksi yang dikombinasikan dengan pengamatan dan analisa visual kegalalan (failure analysis) dengan hasil lokasi pertama komponen struktur yang gagal ditandai dengan kerusakan parah dan indikator lainnya secara forensik sehingga pemeriksaan kegagalan fokus pada lokasi salah satu komponen struktur tersebut. Ketiga melakukan pemeriksaan dengan NDT (Non Destructive Test) dengan Hammer test digital merk Proceq dan melakukan analisa hasil kekuatan beton dengan konversi ke $\mathrm{MPa}$ (Megapascal atau $\mathrm{Kg} / \mathrm{Cm}^{2}$ ) dan memeriksa diameter penulangan. 
Keempat dari data penulangan dan kekuatan beton menjadi parameter-parameter data input dalam program SAP 2000, kemudian SAP 2000 memodelkan struktur sebelum terjadi kegagalan dengan memasukkan model struktur, penampang struktur, kombinasi pembebanan (load combinasion), analisis model struktur. Kelima dari hasil Analisis SAP 2000 dapat diperoleh Gaya dalam berupa Gaya Aksial, Momen yang terjadi pada struktur kolom kemudian dilakukan analisa perhitungan kekuatan penampang kolom dan penulangan yang didalamnya terdapat perhitungan Eksintrisitas Kolom (e), Pemeriksaan Kelangsingan Kolom (portal tak bergoyang, k=1), Kekuatan Penampang Kolom, berdasarkan SNI 03-2847-2002 poin 12.3 5) "tentang prinsip perencanaan komponen struktur yang dibebani beban aksial". Kemudian hasil kuat penampang dibandingkan dengan beban ultimate dan beban aksial yang dapat diketahui bahwa mampu tidaknya komponen struktur dalam menerima beban. Ke enam mengalisa dan menyimpulkan dari keseluruhan hasil pemeriksaan dengan peraturan Pelaksanaan dan penulangan pada SNI 032847-2002.

\section{HASIL DAN PEMBAHASAN}

\section{Pemeriksaan tingkat kerusakan struktur yang mengalami kegagalan}

Lantai 3 (tiga) dan 2 (dua) pada kolom, balok dan plat lantai yang merupakan komponen struktural bangunan rumah tinggal mengalami kerusakan akibat keruntuhan di lantai 1 (satu). Balok dari beton bertulang lantai 3 (tiga) dan 2 (dua) berukuran sekitar $33 \times 12$ centimeter. Kolom dari beton bertulang lantai 3 (tiga) dan 2 (dua) berukuran sekitar 33 x 10 centimeter. Plat lantai dari beton bertulang dengan metal deck lantai 3 (tiga) dan 2 (dua) berukuran tebal sekitar 10 centimeter. Pemeriksaan tingkat kerusakan beton bertulang pada kolom, balok dan plat lantai tersebut menunjukkan makin ke arah bawah (lantai 1) semakin parah, dilantai 1 (satu) terkumpul semua struktur diatasnya yang menunjukkan telah terjadi kerusakan pada lantai 1 akibat beban tekan dari lantai diatasnya (lantai 2 dan 3).

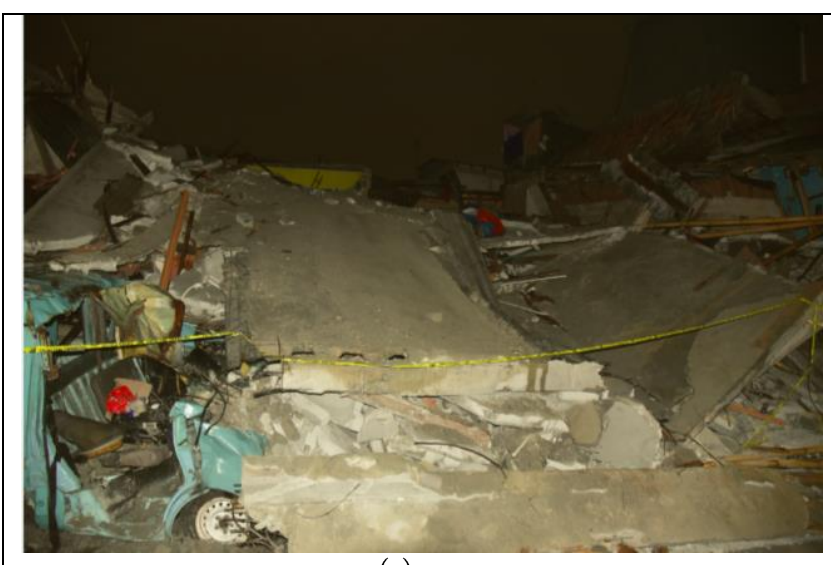

(a)

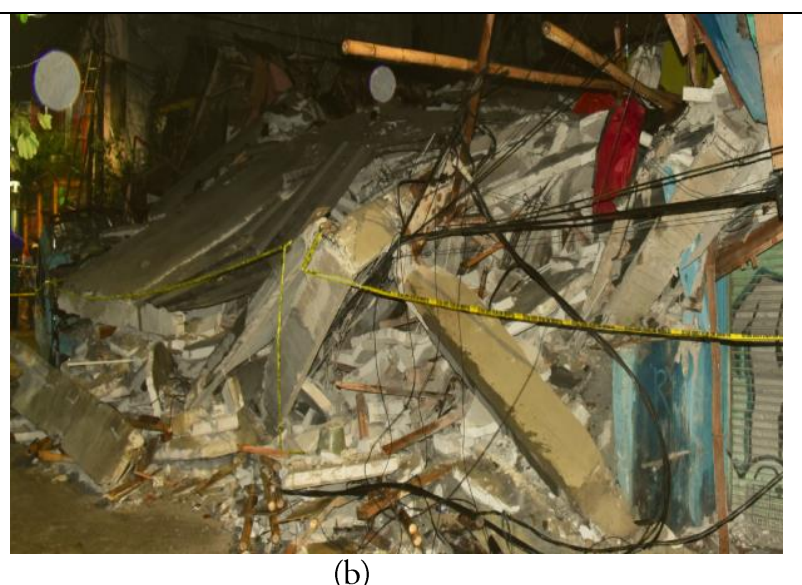

(b)

Gambar 1. (a) Bangunan 3 Lantai yang mengalami kegagalan, (b) Dilihat dari samping Kiri Bangunan

Lantai 1 (satu) mengalalami kerusakan parah akibat beban/gaya tekan dari arah atas (lantai $2 \& 3$ ). Plat beton bertulang dan balok diatasnya mengalami kerusakan dan telah runtuh ke arah bawah lantai 1, pemeriksaan pada struktur betonnya ditemukan pada sisi Selatan yang menumpu pada Struktur kolom sisi Selatan mengalami kerusakan parah dibanding dengan Utara 
Wibawa, T. K., Amri, I. S. Analisis Forensik Kegagalan Konstruksi ...

akibat struktur kolom dibawahnya hancur. Hal tersebut menunjukkan bahwa beban tertumpu pada Kolom perimeter sisi Selatan yang menjadikan penopang beban/gaya struktur yang ada diatasnya (lantai 2 dan 3), sehingga titik kritis hanya pada kolom tersebut.

Ditemukan Kolom beton bertulang di lantai 1 berjumlah 10 (sepuluh) unit dengan ukuran sekitar $33 \times 10$ centimeter, dengan besi polos tulangan pokok dengan diameter 12 millimeter berjumlah 6 unit, sengkang dari besi tulangan polos diameter 7 millimeter dengan jarak sekitar 25 centimeter. Kolom beton bertulang pada sisi Utara berjumlah 5 (lima) unit dan sisi Selatan berjumlah 5 (lima) unit mengalami kerusakan tekan pada strukturnya. Pemeriksaan pada Kolom tersebut makin ke arah Selatan semakin parah dan ditemukan kerusakan tipe buckling/tekuk pada kolom tersebut sehingga menyebabkan hancur akibat tekanan dari arah atas (lantai 2 dan 3). Hal tersebut menunjukkan bahwa telah terjadi kerusakan parah pada kolom yang menopang beban/gaya struktur yang ada diatasnya (lantai 2 dan 3), sehingga titik kritis tertumpu pada kolom dan menyebabkan keruntuhan dan kegagalan struktur diatasnya.

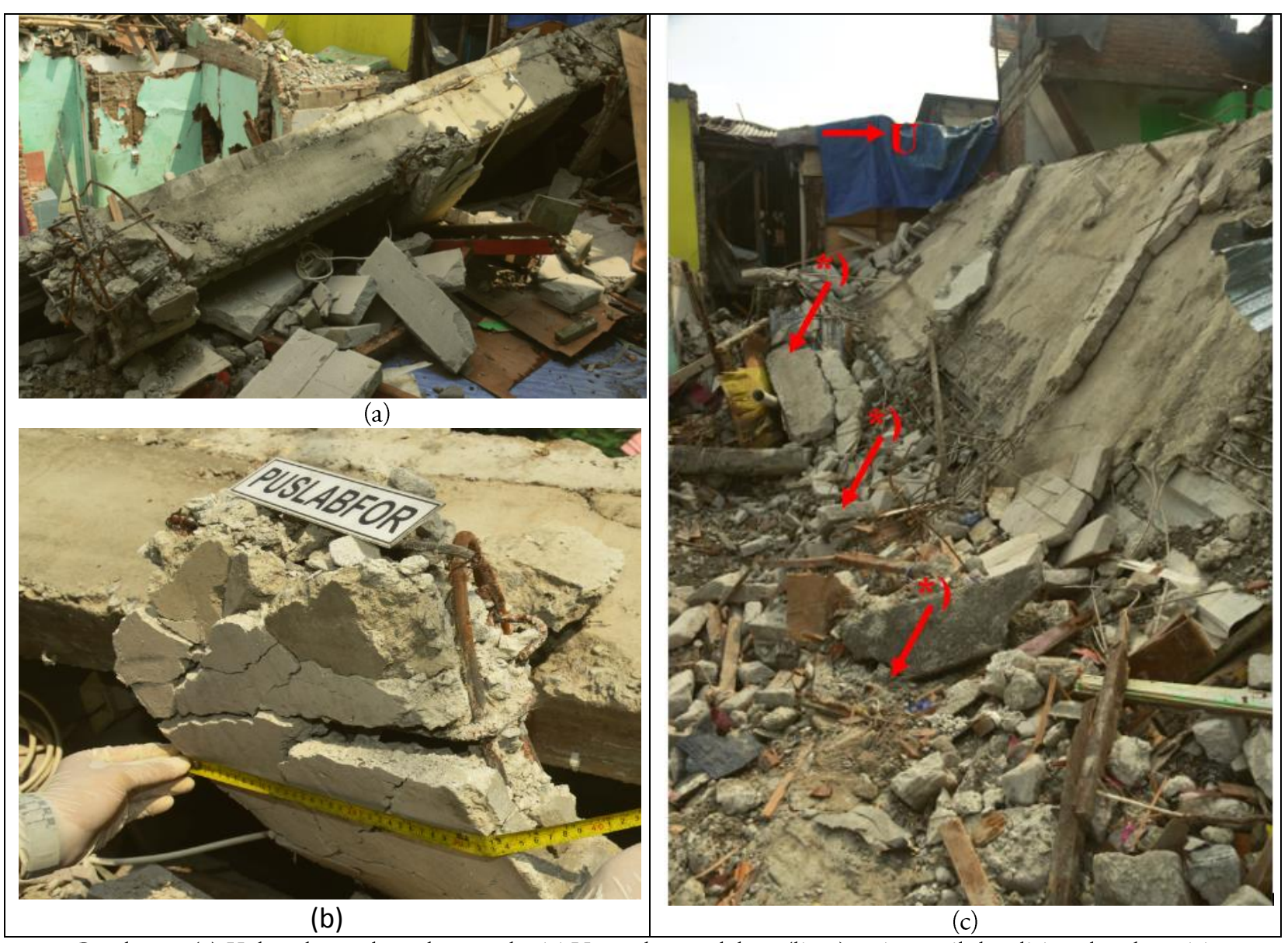

Gambar 2. (a) Kolom beton bertulang pada sisi Utara berjumlah 5 (lima) unit, masih berdiri, sedangkan sisi Selatan telah hancur, (b) Kolom lantai 1 mengalami kerusakan dan mengalami keruntuhan tekan pada pertemuan kolom terhadap balok (c) Kolom sisi Selatan lantai 1 telah Hancur, Titik kritis tertumpu pada kolom sisi Selatan yang menyebabkan keruntuhan dan kegagalan struktur

Kolom adalah komponen utama dalam struktur bangunan yang tugas utamanya menyangga beban aksial tekan vertikal. Kolom merupakan suatu elemen struktur tekan yang memegang peranan penting dari suatu bangunan yang memikul beban dari balok, plat dan beban 
diatasnya sehingga beban dapat tertransfer/diteruskan ke pondasi. Kolom menopang beban keseluruhan konstruksi harus memenuhi kaidah standar pembesian, pembetonan dalam perencanaan dan kaidah standar dalam pelaksanaan konstruksi

\section{Pemeriksaan sampel dengan Hammer Test Digital Merk Proceq}

Hasil pemeriksaan Non Destructif Test (NDT) pada contoh Kolom Lantai 1 dengan menggunakan Hammer Test Digital Merk Proceq.

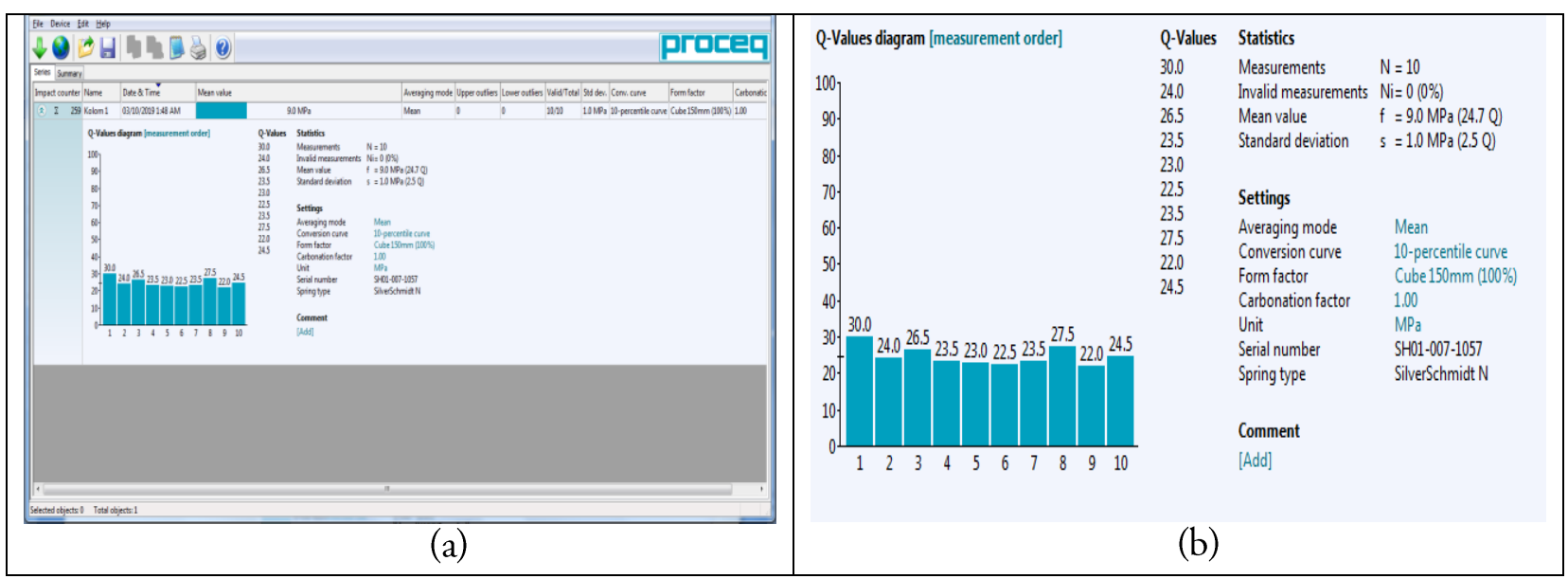

Gambar 3. (a) Hasil Pengujian Hammer Test dan Pengolahan data dengan Aplikasi Proceq (b) Hasil 10 sepuluh sampel pengujian hammer test.

Dari 10 (sepuluh) pengujian didapatkan nilai Kuat Tekan Beton rata-rata sebesar $9 \mathrm{MPa}$ atau Senilai $9 \mathrm{~N} / \mathrm{mm}^{2}$. Merujuk pada SNI 2847:2013 tentang persyaratan beton struktural untuk bangunan gedung, pada pasal 5 tentang kualitas, pencampuran dan pengecoran beton menyebutkan bahwa "Nilai fc atau kuat tekan beton yang digunakan pada bangunan gedung yang direncanakan sesuai dengan aturan-aturan dalam Standar ini, tidak boleh kurang daripada $17 \mathrm{MPa}$ ". Dari hasil uji Hammer Test tersebut menunjukkan bahwa nilai kuat tekan rata-rata beton kolom sebesar $9 \mathrm{MPa}$, tersebut lebih kecil dari standar yang ada yaitu $17 \mathrm{Mpa}$. Kualitas beton yang nilainya kurang dari standar disebabkan karena pekerjaan manual (mix in situ) dan tidak menggunakan kontrol kualitas mutu beton standart (Job Mix Design) yang dipersyaratkan. 
Wibawa, T. K., Amri, I. S. Analisis Forensik Kegagalan Konstruksi ...

\section{Pemodelan dengan SAP 2000 dan Analisis Kekuatan Penampang Kolom}

Analisis dan Pemodelan Menggunakan SAP (Structure Analysis Program) 2000 didapatkan semulasi sebagai berikut:

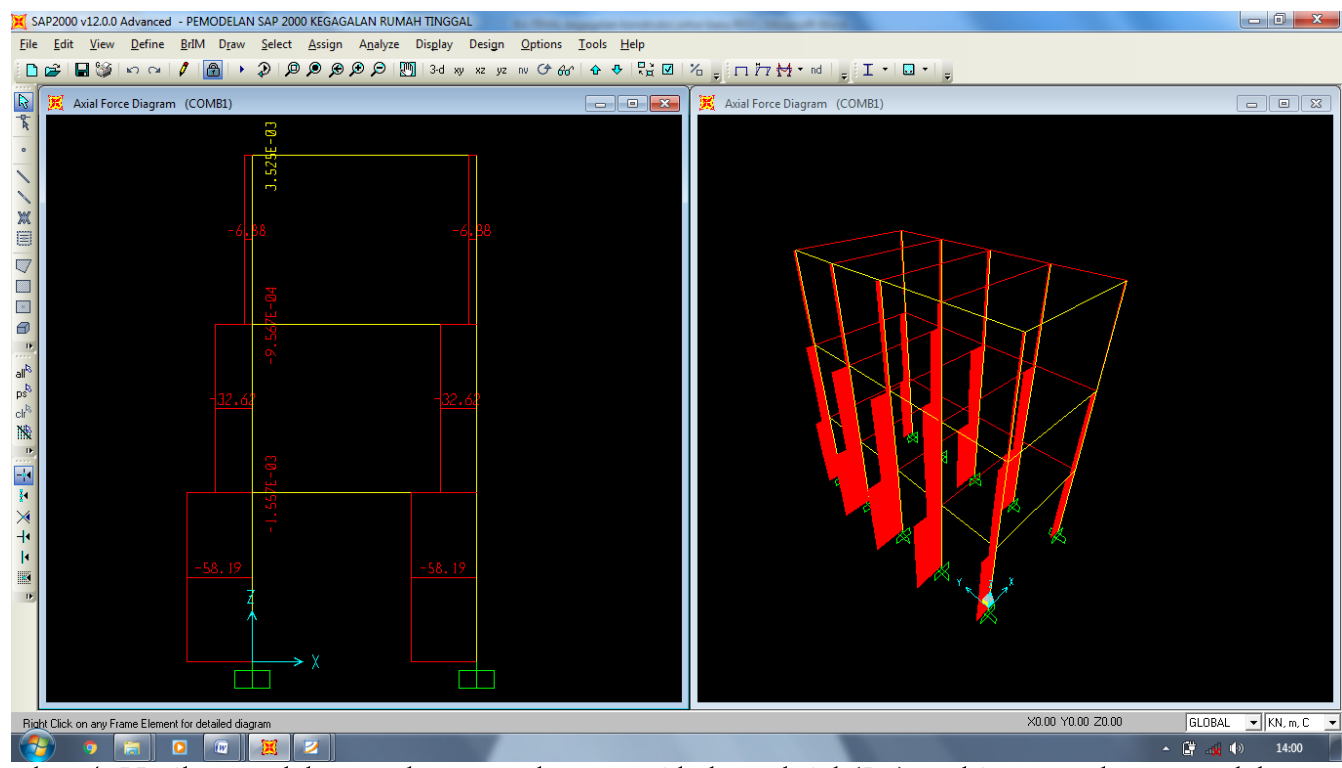

Gambar 4. Hasil pemodelan struktur untuk mencari beban aksial $(\mathrm{Pu})$ perhitungan dan pemodelan struktur Program SAP 2000 (Structure Analize Program).

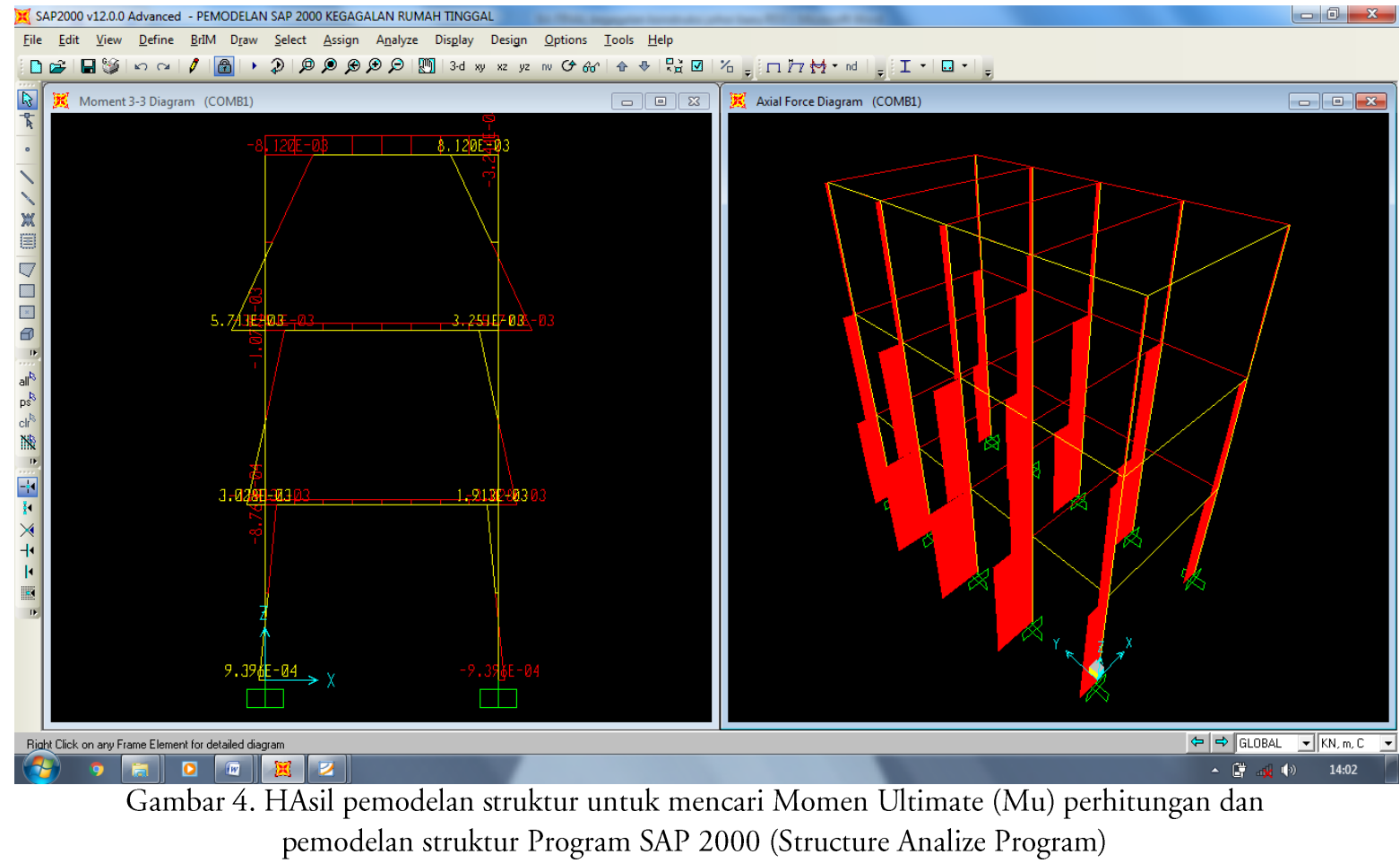

\section{Analisa Kekuatan Penampang Kolom}

Data dari pemeriksaan lapangan dan analisa kombinasi pembebanan SNI 1727:2013 dengan kombinasi pembebanan 1,2 DL + 1,6 LL sebagai berikut: Kolom dimensi : $300 \mathrm{~mm} \times 100 \mathrm{~mm}$ Mutu Beton lapangan $(\mathrm{f} c)=9 \mathrm{MPa}$ 
Baja Tulangan Fy (tulangan polos) $=240 \mathrm{Mpa}$

Kolom Dipasang Tulangan $6 \phi 12$

Beban Aksial $(\mathrm{Pu})=2,8395$ ton $=28,395 \mathrm{KN}$ per 1 Kolom

Momen Ultimate $(\mathrm{Mu})$ didapat dari pemodelan SAP $2000=0,458 \mathrm{kN} . \mathrm{m}$

Perhitungan Kekuatan Penampang Kolom sesuai dengan dasar SNI 03-2847-2002 tentang “ tata cara perhitungan struktur beton untuk bangunan gedung" yaitu:

1. Luas Tulangan (Ast) $=6 \phi 12==6 \times 1 / 4 \times \pi \times 12^{2}=678,24 \mathrm{~mm}^{2}$

2. Luas Beton $(\mathrm{Ag})=330 \times 100=33.000 \mathrm{~mm}^{2}$

3. Pemeriksaan Eksintrisitas Kolom (e) $=\mathrm{Mu} / \mathrm{Pu}=0,458 \mathrm{kN} . \mathrm{m} / 28,395 \mathrm{kN}=0,016 \mathrm{~m}$

$\mathrm{e}_{\min }=0,1 \times \mathrm{h}=0,1 \times 100=10 \mathrm{~mm}, \mathrm{e}=1,6 \mathrm{~cm}>\mathrm{e}_{\min }(=1 \mathrm{~cm})$

$\mathrm{e}>\mathrm{e}_{\min }$, maka nilai tersebut menunjukkan terjadi eksentrisitas yang dapat menyebabkan keruntuhan tekan

4. Pemeriksaan Kelangsingan Kolom (portal tak bergoyang, k=1)

$\frac{K \cdot \lambda}{r}=\frac{1.300 \mathrm{~cm}}{0,3 \times 33 \mathrm{~cm}}=30,30$, Dari hasil diatas menunjukkan bahwa $\frac{\frac{K \cdot \lambda}{r}}{r}$ adalah 30,3 yang menunjukkan $\frac{K \cdot \lambda}{r}>22$ adalah nilai Kolom Langsing

5. Kekuatan Penampang Kolom, berdasarkan SNI 03-2847-2002 poin 12.3 5) "tentang prinsip perencanaan komponen struktur yang dibebani beban aksial"

Beban aksial yang terjadi pada kolom $=[0,85 \mathrm{x} \mathrm{fc} x(\mathrm{Ag}-\mathrm{Ast})+$ Ast $\mathrm{x}$ fy $]$

$$
\begin{aligned}
& =[0,85 \times 9 \times(33.000-678,24)+678,24 \times 240] \\
& =410.039,064 \mathrm{~N}
\end{aligned}
$$

Menghitung Kapasitas Penampang pada keruntuhan tekan

Pn Maks $=0,8 \times$ Po.

Pn Maks $=0,8 \times[0,85 \times \mathrm{fc} \times($ Ag-Ast $)+$ Ast $\mathrm{x}$ fy $]$.

$$
\begin{aligned}
& =0,8 \times[0,85 \times 9 \times(33.000-678,24)+678,24 \times 240] \\
& =328031,25 \mathrm{~N}=32,80 \text { ton }
\end{aligned}
$$

Maka Kemampuan Penampang Kolom $=328,031 \mathrm{KN}=32,80$ ton. Sedangkan beban Aksial $(\mathrm{Pu})=2,8395$ ton $=28,395 \mathrm{KN}$. Dan beban aksial $(\mathrm{Pu})$ perhitungan dan pemodelan struktur Program SAP 2000 (Structure Analize Program) yaitu senilai: 58,19 KN = 5,819 ton.

Maka, Kuat Penampang Kolom > Beban aksial ultimite > beban aksial, Pn Maks (32,80 ton) > $\mathrm{Pu}(5,819)>\mathrm{Pu}(2,8395)$.

Maka dari luas Penampang Kolom, nilainya masih mampu/aman menahan beban struktur diatasnya, sehingga dilakukan pemeriksaan secara detail pada standar dan tatacara pelaksanaan penulangan dilapangan sehingga ditemukan penyebab keruntuhan pada struktur kolom. 
Wibawa, T. K., Amri, I. S. Analisis Forensik Kegagalan Konstruksi ...

\section{Hasil Analisa Pelaksanaan dan penulangan Kolom}

Pada Penulangan kolom ditemukan besi Tulangan $6 \phi 12$ (tulangan polos), dan sengkang $\phi$ 12 - jarak $250 \mathrm{~mm}$, dilakukan pemeriksaan secara detail pada standar dan tatacara pelaksanaan penulangan dilapangan:

1. Pemeriksaan pada penulangan tekukan untuk sengkang dalam menahan beban tekan dari dimensi pembesian kolom ditekuk hanya $90^{\circ}$ dan tidak sesuai dengan peraturan SNI 2847:2013 pada detail pembesian tekukan sengkang untuk kolom yang ditekuk sebesar $135^{\circ}$

Pada peraturan SNI 2847:2013 poin 7.10.5.3 tentang pengikat komponen struktur tekan harus menyebutkan "Pengikat persegi harus disusun sedemikian hingga setiap sudut dan batang tulangan longitudinal yang berselang harus mempunyai tumpuan lateral yang disediakan oleh sudut pengikat dengan sudut dalam tidak lebih dari 135 derajat dan tidak boleh ada batang tulangan lebih jauh dari $150 \mathrm{~mm}$ bersih pada setiap sisi sepanjang pengikat dari batang tulangan yang tertumpu secara lateral. Jika tulangan longitudinal terletak di sekeliling perimeter suatu lingkaran, pengikat berbentuk lingkaran penuh diizinkan"

2. Pemeriksaan jarak sengkang pada kolom lantai 1 ditemukan tidak sesuai yang disyaratkan pada peraturan SNI 2847:2013 poin 7.10.5.2 tentang pengikat/sengkang yang berbunyi "Spasi vertikal pengikat tidak boleh melebihi 16 kali diameter batang tulangan longitudinal, 48 kali diameter batang tulangan atau kawat pengikat, atau ukuran terkecil komponen struktur tekan"

Ditemukan dilapangan sengkang $\phi 7-$ jarak $250 \mathrm{~mm}=25 \mathrm{~cm}$.

Batang tulangan utama $6 \phi 12$.

Dibanding dengan peraturan spasi sengkang menurut SNI yaitu tidak boleh melebihi $16 \mathrm{x}$ diameter $12 \mathrm{~mm}=192 \mathrm{~mm}=19,2 \mathrm{~cm}$.

Maka nilai sengkang dilapangan $(25 \mathrm{~cm})>$ standart SNI (minimum 19,2 cm).

Hal tersebut dapat mengakibatkan berkurangnya ikatan pengikat sengkang kolom dalam menahan beban aksial (tekan) dan tidak sesuai dengan syarat minumum struktur yang dapat menyebabkan keruntuhan.

Kolom direncanakan dan dilaksanakan pada tahap konstruksi dengan tidak standart yang tidak sesuai dengan peraturan(code) SNI (Standar Nasional Indonesia) pada kuat tekan Beton, panjang spasi sengkang, dan detail tekukan besi pada penulangan kait sengkang kolom, maka dapat berkurangnya kekuatan dan kemampuan strktur dalam menahan beban aksial (tekan) dan apabila syarat minumum dalam kaidah struktur tersebut tidak terpenuhi sehingga terjadi ketidakseimbangan beban pada struktur kolom dan mencari lokasi stuktur paling lemah yaitu beton bertulang pada 5 (lima) kolom lantai 1 sisi Selatan kemudian yang dapat menyebabkan deformasi dan keruntuhan (building failure) pada struktur diatasnya (plat lantai, balok) serta memberikan efek domino terhadap keruntuhan total (total collapse) seluruh komponen struktur diatasnya.

\section{Penutup}

Berdasarkan penelitian ini, disimpulkan bahwa keruntuhan awal berada pada Kolom ukuran 33 x 10 centimeter di bagian sisi Selatan lantai 1 bangunan dengan keruntuhan tipe 
buckling/tekuk sehingga menyebabkan hancur akibat tekanan dari arah atas (lantai 2 dan 3), Uji Sample Beton dengan Hammer Test Digital Merk Proceq dari 10 (sepuluh) pengujian didapatkan nilai Kuat Tekan Beton rata-rata sebesar $9 \mathrm{MPa}$ atau Senilai $9 \mathrm{~N} / \mathrm{mm}^{2}$. Hasil pemodelan struktur Program SAP 2000 (Structure Analize Program) dan perhitungan kekuatan penampang kolom didapatkan kapasitas kekuatan penampang kolom yaitu 32,80 ton, nilai terebut masih mampu/aman menahan beban struktur diatasnya. Kegagalan dan keruntuhan kolom diakibatkan jarak antar sengkang ditemukan yaitu $25 \mathrm{~cm}$ melebihi dari batas persyaratan pelaksanaan dalam peraturan SNI 2847:2013 poin 7.10.5.2 dan ditemukan penulangan kolom pada tekukan sengkang dalam menahan beban tekan dari dimensi pembesian kolom ditekuk hanya $90^{\circ}$ dan tidak sesuai dengan peraturan SNI 2847:2013 pada detail pembesian tekukan sengkang untuk kolom yang ditekuk sebesar $135^{\circ}$, Sehingga struktur tidak mampu menahan beban konstruksi diatasnya (beban plat lantai, balok, kolom dan lainnya) akibat kolom direncanakan dan dilaksanakan pada tahap konstruksi dengan tidak standart yang tidak sesuai dengan SNI (Standar Nasional Indonesia) pada panjang spasi sengkang, dan detail tekukan besi pada penulangan kait sengkang kolom yang dapat menyebabkan keruntuhan tipe buckling/tekuk.

Penelitian ini dapat dikembangkan dengan metode pemodelan struktur lainnya yaitu ETABS untuk pemeriksaan struktur lanjutan sebagai evaluasi kapasitas struktur dan dapat dikombinasikan dengan menggunakan pendekatan alat/instrument forensik kegagalan lainnya seperti UPV (ultrasonic Pulse Velocity), VUCON, Rebarscope dan alat forensik lainnya.

\section{Daftar Pustaka}

Cook G.K., Hinks A.J., 1992. Appraising Building Defect. England: Longman Scientific \& Technical.

Daniel L. Schodek. (1999), “Struktur”, Penerbit Erlangga, Jakarta

Muhammad Amry, Sarwono Hardjomuljadi dan Chaidir Anwar Makarim. 2019. Kegagalan Konstruksi Dan Kegagalan Bangunan Dalam Perspektif Keberlanjutan Konstruksi. Bandung. Prosiding Konferensi Nasional Pascasarjana Teknik Sipil (KNPTS) X 2019 "Adaptasi dan Mitigasi Bencana dalam Mewujudkan Infrastruktur yang Berkelanjutan".

Prayitno Osmar Dangga, Munasih, Lila Ayu Ratnawinda. 2020. Kajian Faktor - Faktor Penyebab Kecelakaan Konstruksi. Malang. Student Journal GELAGAR Vol. 2 No.2 2020 Program Studi Teknik Sipil S1, ITN MALANG.

Robert T. Ratay, Ph.D., P.E. 2000. Forensic Structural Engineering Handbook. New York. MCGRAW-HILL.

Rekha Shinde and Kundan Meshram, 2020, International Journal Of Scientific \& Technology Research Volume 9, ISSUE 04 April 2020. India. IJSTR

Rina Rusdiani. 2017. Analisis Kegagalan Konstruksi Pada Bangunan Gedung Di Provinsi Jawa Barat. Bandung. Tesis Program Magister Teknik Sipil Program Pascasarjana Universitas Katolik Parahyangan Bandung.

SNI 03-2847-2002 tentang “tata cara perhitungan struktur beton untuk bangunan gedung”. 2002. Bandung.

Tatang Guritno. 2019. Megapolitan.kompas.com/read/2019/04/27/09131121/fakta-rumahambruk-di-johar-baru-bangunan-ilegal-yang-makan-korban-jiwa?page=all, diakses tanggal 1 Oktober 2021. 
Wibawa, T. K., Amri, I. S. Analisis Forensik Kegagalan Konstruksi ...

Yustinus Eka Wiyana, 2012. Analisis Kegagalan Konstruksi Dan Bangunan Dari Perspektif Faktor Teknis. Semarang. Wahana TEKNIK SIPIL Vol.17 No.2 Desember 2012. 